\title{
ANALISIS INFORMASI CITRA ANATOMI MSCT SCAN ORBITA POTONGAN AXIAL DENGAN VARIASI KERNEL DENGAN WINDOW SINUS DAN WINDOW BASE ORBITA PADA KASUS TRAUMA
}

\author{
Endang Dwi Endarti ${ }^{1}$, Jeffry Ardianto $^{2}$, Andrey Nino Kurniawan ${ }^{3}$ \\ ', PKU Muhammadiyah Hospital Karanganyar \\ ${ }^{2,3}$ Jurusan Teknik Radiodiagnostik dan Radioterapi, Poltekkes Kemenkes Semarang, Indonesia \\ Email: endangendang789@gmail.com
}

\begin{abstract}
Background: Trauma on the Orbits is very precisely evaluated by MSCT Scan and can analyze well the bone structure and surrounding soft tissue. One of the main parameters on MSCT Scan is the algorithm or kernel reconstruction. The improper use of the kernel can affect spatial resolution and contrast resolution, so evaluating MSCT Scan image information of Orbits with the use of window and the kernel variation is the main problem discussed. The purpose of this study was to determine differences in anatomical information on MSCT Scan of Orbits images with sinuses window variations and base orbits window with kernel of H30s Medium Smooth, H40s Medium, H70s Sharp in trauma cases and find out the best window and kernel variations in displaying anatomical information of Orbits MSCT Scan.

Methods: This research is quantitative research. The research subjects were 2 Radiology Specialists as research respondents. The sample used was 10 patients. The raw data acquisition that has been obtained is reconstructed into a sinuses window and orbits base window with kernel H30s Medium Smooth, H40s Medium, H70s Sharp. Data obtained between respondents were carried out by the Cohen's Kappa test, then the Friedman test with significance $<0.05$ and the best variation was obtained from the mean rank Friedman test.

Results: The results of the study show that. In the variation of medium smooth H30s window and medium H40s and very sharp H70s sinus window featuring orbital walls. and most clearly in the sinus window H70s very sharp. In the window base the orbitals H30s medium smooth and H40s medium. Show clarity in the anterior chamber, lens and medial rectus muscle.

Conclusion: The orbital H70s window base is very sharp showing clarity on the optic nerve, anterior chamber, lateral rectus muscle and orbital wall. Based on the results of the mean rank, the Friedman test showed that variations in the orbits window base with the Sharp H70s kernel were the best variations in each anatomic area.
\end{abstract}

Keyword: MSCT Scan, Orbits, Windowing, Kernel

\section{Pendahuluan}

Orbita merupakan organ berbentuk buah pir, dengan nervous optikus sebagai tangkainya. Lingkaran anterior lebih kecil sedikit dari pada lingkaran di bagian dalam tepiannya yang merupakan pelindung yang kuat. Orbita berisi otot penggerak bola mata, nervus optikus, glandula lakrimalis, dan lemak. Sinus frontalis, sinus maksilaris bawah, sinus ethmoidalis dan sinus spenoidal medial berhubungan langsung dengan orbita. Dasar orbita yang tipis mudah rusak oleh trauma langsung terhadap bola mata. Infeksi sinus ethmoidalis dan spenoid dapat mengikis dinding medialnya yang sangat tipis seperti kertas (lamina papyracea) dan mengenai orbita. ${ }^{[1]}$

Trauma mata atau orbita merupakan kerusakan yang mengenai jaringan mata dan bagian penyokong mata seperti tulang orbita. Trauma ini dapat terjadi akibat kecelakaan lalu lintas (KLL) ataupun terkena benda tumpul lainnya yang mengenai area orbita. ${ }^{[2]} \mathrm{Di}$ Indonesia, berdasarkan hasil Riset Kesehatan Dasar (RISKESDAS) pada tahun 2013, trauma pada mata dan orbita termasuk ke dalam 6 jenis trauma terbanyak yang terjadi di Indonesia dan menempati urutan kelima jenis trauma yang paling sering terjadi pada tahun 2013. ${ }^{[3]}$ Menurut Wahab (2014), fraktur orbita adalah fraktur kompleks yang sering terjadi, dan dinding orbita yang 
paling sering mengalami retak. Potongan axial dari MSCT orbita mampu menampakkan dengan jelas dinding lateral dan medial dari orbita. ${ }^{[4]}$

Multi-slice Computed Tomography (MSCT) Scan adalah metode pencitraan paling sensitif untuk mendeteksi ruptur yang tersembunyi, hal-hal yang terkait dengan kerusakan saraf optic, adanya benda asing serta menampilkan anatomi dari bola mata dan orbita. Sebagai salah satu sarana penunjang penegakan diagnosa yang menggunakan gabungan dari sinar-x dan komputer untuk mendapatkan citra atau gambar berupa variasi irisan tubuh manusia. Sebagai alat untuk menunjang penegakan diagnosa MSCT Scan diharapkan dapat memberikan gambaran yang informatif, terutama informasi anatomis yang dikehendaki. ${ }^{[5]}$

Kualitas citra MSCT Scan terdiri dari beberapa komponen yang dipengaruhi oleh parameter-parameter. Komponen tersebut terdiri dari resolusi spasial, resolusi kontras, noise, dan artefak. Sedangkan parameter yang mempengaruhinya antar lain faktor eksposi, pitch, slice thickness, rekonstruksi algoritma atau filter dan windowing. Rekonstruksi algorithma atau yang disebut juga kernel mempunyai parameter yang sebutannya berbeda-beda. Rekonstruksi algorithma adalah prosedur matematis yang digunakan dalam merekonstruksi gambar dan akan mempengaruhi resolusi spatial, resolusi kontras dan noise. ${ }^{[5]}$

Penggunaan kernel yang tidak tepat dapat berpengaruh terhadap resolusi spasial dan resolusi kontras. Kernel tulang memiliki resolusi spasial yang paling baik, tetapi menghasilkan resolusi kontras rendah sedangkan kernel jaringan lunak memiliki resolusi spasial yang rendah, tetapi akan menghasilkan resolusi kontras yang rendah. Semakin tinggi rekonstruksi kernel yang dipilih maka semakin tinggi resolusi citra yang dihasilkan. ${ }^{[6]}$ Seeram (2016) menambahkan bahwa dengan penggunaan kernel yang tepat, gambaran seperti tulang, soft tissue, dan jaringan-jaringan lain dapat dibedakan dengan jelas pada layar monitor. Kernel untuk resolusi tinggi mampu memperjelas tepian atau ujung-ujung citra sehingga menghasilkan image yang lebih baik tetapi level noisenya akan lebih tinggi, sedangkan kernel smooth memiliki level noise yang rendah tetapi ujung tepian dari gambar menjadi tidak jelas. Semakin tinggi nilai image nosie maka dapat dikatakan bahwa kualitas gambar CT Scan akan semakin menurun, sebaliknya semakin rendah nilai image nosie maka kualitas gambar yang dihasilkan akan semakin baik. Kernel sangat beragam dan selalu dimodifikasi untuk hasil yang lebih bagus. Hal inilah yang membuat hasil image yang berbeda-beda untuk beberapa vendor. ${ }^{[5]}$

Salah satu vendor CT Scan mengembangkan kernel menjadi 4 jenis kernel, yaitu: $\mathrm{H}$ untuk Head, B untuk Body, C untuk Child Head dan S untuk Special Application. Kode " $\mathrm{H}$ " pada masing-masing rekonstruksi mengartikan "Head" atau algorithma yang dikhususkan untuk pemeriksaan CT Scan Head, kemudian di ikuti oleh angka yang mengartikan tingkatan masing-masing algortima. Angka algoritma dikembangkan menjadi 5 jenis, yaitu: 5 jenis, yaitu: 20 (smooth), 30 (medium smooth), 40 (medium), 50 (sharp) dan 70 (very sharp), semakin tinggi angka algoritma maka akan semakin tajam gambaran yang akan dihasilkan. Selanjutnya yaitu kode filter yang dinyatakan dalam huruf dan dikembangkan dalam 4 jenis mode yaitu: $f$ (fast), s (standard), h (highresolution) dan $u$ (ultrahighresolution). Penggunaan filter yang semakin tinggi akan menghasilkan gambaran dengan resolusi yang semakin tinggi pula. ${ }^{[7]}$

Selain pengaturan kernel, algorithma dan filter, pengaturan windowing juga sangat berpengaruh terhadap kualitas citra MSCT Scan Orbita. Windowing juga dikenal sebagai skala keabuan (gray-level mapping) yang merupakan proses manipulasi dari skala keabuan CT Numbers. Pada pengaturan windowing dikenal juga Window Level (WL) yang akan mempengaruhi tingkat kecerahan (brightness) citra dan Window Width (WW) yang akan mempengaruhi tingkat ketajaman (contrast) citra. Perubahan windowing akan mempengaruhi tampilan struktur anatomis dan kualitas dari sebuah citra. ${ }^{[5]}$

Potokol pemeriksaan MSCT Scan Orbita di RS PKU Muhammadiyah Kabupaten Karanganyar dengan menggunakan protokol Head routine, window base orbita dan kernel H.31s medium smoth sesuai dengan protokol standar yang tersedia di Pesawat CT Siemens 16 slices, kemudian direkonstruksi dengan menggunakan window sinus. Penggunaan protokol window sinus (WW 2000, WL 400) dan window base orbita (WW 120, WL 40) serta banyaknya variasi algoritma dari smooth hingga sharp ( H30s medium smooth,H40s medium,H70s very sharp) pada protokol MSCT Scan Orbita membuat penulis tertarik untuk melakukan penelitian dan mengangkatnya sebagai penelitian yang menekankan pada window dan variasi kernel dengan tujuan mengetahui kernel dengan window manakah yang dapat menghasilkan informasi citra anatomi terbaik pada pemeriksaan MSCT Scan Orbita. Selanjutnya penulis akan mengkaji lebih dalam dan mengangkat topik ini sebagai bentuk karya tulis ilmiah dengan judul "Analisis Perbedaan Informasi Citra Anatomi MSCT Scan Orbita Potongan Axial dengan Variasi Kernel pada Window Sinus dan Window Base Orbita pada Kasus Trauma“.

\section{Metode}

Jenis penelitian dalam tugas akhir ini adalah penelitian kuantitatif dengan pendekatan eskperimental untuk mengetahui hasil informasi anatomi citra MSCT Scan Orbita potongan axial dengan variasi kernel pada windows sinus dan window base orbita dan mengetahui variasi kernel dan window manakah yang mampu menghasilkan informasi citra anatomi orbita yang optimal pada kasus trauma.

Penelitian ini akan dilaksanakan di Instalasi Radiologi RS PKU Muhammadiyah Kabupaten Karanganyar, karena memiliki modalitas MSCT Scan 16 slice yang dapat digunakan untuk pemeriksaan 
MSCT Scan Orbita. Lamanya waktu yaitu pada bulan Maret 2019 - Mei 2019.

Penentuan jumlah sampel pada penelitian ini menggunakan rumus Slovin ${ }^{[8]}$ dengan tingkat kepercayaan 95\%, sehingga didapatkan perhitungan sebagai berikut:

$$
n=\frac{N}{1+N e^{2}}=\frac{10}{1+10(0.05)^{2}}=9.75=10 \text { sampel } .
$$

Berdasarkan hasil perhitungan jumlah sampel diatas, maka peneliti akan menggunakan sampel penelitian sebanyak 10 sampel MSCT Scan Orbita dengan variasi rekonstruksi kernel pada window sinus dan window base orbita.

- Akuisisi data (raw data) yang telah didapatkan direkonstruksi menjadi 6 citra MSCT Orbita pasien trauma yang direkontruksi menggunakan 2 variasi window yaitu window sinus dan window base orbita serta 3 variasi kernel yaitu B30s Medium Smooth, B40s Medium dan B70s Very Sharp. Anatomi yang dilaukan penilaian adalah Optic Nerve, Anterior Chamber, Medial Rectus Muscle, Lens, Lateral Rectus Muscle dan Dinding Orbita. Data yang didapatkan antar responden dilakukan uji Cohen's Kappa, kemudian dilakukan uji Friedman dengan signifikansi $<0.05$ dan variasi terbaik didapatkan dari mean rank uji Friedman.

\section{Hasil dan Pembahasan}

Setiap hasil citra dari pasien MSCT Scan Orbita tersebut dihasilkan 20 slice potongan axial citra MSCT Scan Orbita kemudian dilakukan rekonstruksi dengan mengunakan 6 variasi yaitu pada window sinus dengan kernel H30s Medium Smooth, H40s Medium, H70s Very Sharp dan window Base Orbita dengan kernel H30s Medium Smooth, H40s Medium, H70s Very Sharp.

Dari hasil potongan axial citra MSCT Scan Orbita yang telah direkonstruksi menggunakan 6 variasi tersebut diambil 1 slice pada slice ke-17 yang dapat menampilkan informasi citra anatomi yang akan dinilai oleh 2 responden. Pengambilan slice ke-17 didasarkan dari konsultasi dengan Dokter Spesialis Radiologi yang menerangkan bahwa pada citra MSCT Scan Orbita, potongan axial slice ke-17 dapat menampakkan keseluruhan anatomi orbita yang akan dinilai, dengan kriteria anatomi Optic Nerve (ON), Anterior Chamber (AC), Medial Rectus Muscle (MRM), Lens (L), Lateral Rectus Muscle (MLM) dan Dinding Orbita (DO).

Windowing dan kernel adalah prosedur matematis yang digunakan dalam merekonstruksi gambar dan akan mempengaruhi resolusi spatial, resolusi kontras dan noise. Pada alat MSCT Scan mampu menghasilkan citra dengan berbagai macam windowing dan kernel. Windowing akan mengatur densitas serta kontras citra, sedangkan kernel akan menghaluskan ataupun menajamkan citra.

Penggunaan kernel yang tidak tepat dapat berpengaruh terhadap resolusi spasial dan resolusi kontras (Bushberg,2012), resolusi spatial adalah kemampuan untuk dapat membedakan obyek yang berukuran kecil dengan densitas yang berbeda pada latar belakang yang sama. ${ }^{[6]}$ Sedangkan resolusi kontras adalah kemampuan untuk membedakan suatu penampakan obyek-obyek dengan perbedaan densitas yang sangat kecil yang dipengaruhi oleh faktor eksposi, slice thicknes, FOV, dan rekonstruksi algorithma. (Seeram, 2011), ${ }^{[5]}$

Kernel tulang memiliki resolusi spasial yang paling baik, tetapi menghasilkan resolusi kontras rendah sedangkan kernel jaringan lunak memiliki resolusi spasial yang rendah, tetapi akan menghasilkan resolusi kontras yang rendah. Di RS PKU Muhammadiyah Kabupaten Karanganyar, menggunakan modalitas MSCT Scan 16 slices.

Hasil dari akuisisi MSCT Scan Orbita menggunakan window base orbita dengan kernel H31s smoth +. Sehingga penting dilakukan penilaian terhadap citra yang dihasilkan. Penelitian ini dilakukan dengan menggunakan teknik rekonstruksi raw data dengan variasi window sinus dengan kernel H30s Medium Smooth, window sinus dengan kernel H40s Medium, window sinus dengan kernel H70s Very Sharp, window base orbita dengan kernel H30s Medium Smooth, window base orbita dengan kernel H40s Medium, dan window base orbita dengan kernel H70s Very Sharp. Pada hasil citra yang telah didapatkan, dapat dilihat, bahwa window sinus menghasilkan citra dengan kontras resolusi yang baik serta densitas citra dominan hitam dan putih, sedangkan pada window base orbita menghasilkan citra dengan kontras resolusi yang baik serta densitas citra hitam dan putih dengan dominasi densitas keabu-abuan (grayscale).

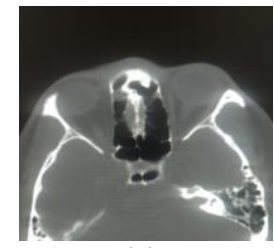

(a)

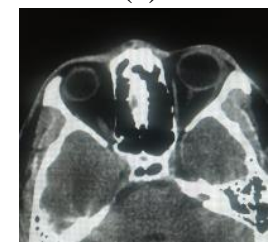

(d)

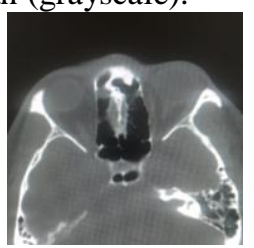

(b)

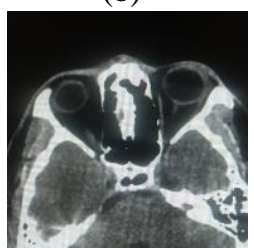

(e)

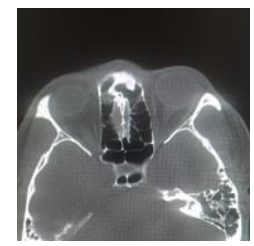

(c)

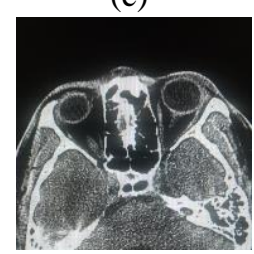

(f)
Gambar. 1. Hasil citra MSCT Scan Orbita potongan axial sampel 1 pada slice ke-12. (a) Window Sinus Kernel H30s Medium Smooth, (b) Window Sinus Kernel H40s Medium, (c) Window Sinus Kernel H70s Very Sharp, (d) Window Base Orbita Kernel H30s Medium Smooth, (e) Window Base Orbita Kernel H40s Medium dan (f) Window Base Orbita Kernel H70s Very Sharp

Dari sampel hasil potongan axial citra MSCT Orbita pada fig. 1 akan dinilai oleh 2 responden. Responden mengisi kuesioner berupa check list yang terdiri dari kriteria anatomi pada citra MSCT Scan Orbita (Optic 
Nerve, Anterior Chamber, Medial Rectus Muscle, Lens, Lateral Rectus Muscle dan Dinding Orbita.). pada window sinus dengan kernel H30s Medium Smooth, H40s Medium, H70s Very Sharp dan window Base Orbita dengan kernel H30s Medium Smooth, H40s Medium, H70s Very Sharp. Kemudian responden mengisi kuesioner tersebut dengan penilaian menggunakan skoring (Skor 1 = Tidak jelas, skor $2=$ Kurang jelas, skor 3 = Jelas).

Hasil citra MSCT Scan Orbita dari salah satu sampel penelitian pada fig. 1, dapat dilihat perbedaan hasil citra secara visual dari penggunaan variasi windowing dengan kernel. Pada penggunaan windowing sinus, dapat dilihat kontras citra yang tinggi sehingga dihasilkan densitas hitam dan putih dengan sedikit densitas abu-abu. Sedangkan pada windowing base orbita, dapat dilihat kontras citra yang cukup tinggi pula dengan densitas hitam dan putih dengan didominasi densitas keabu-abuan (grayscale). Pada penggunaan kernel dapat dilihat kernel H30s Medium Smooth menghasilkan citra dengan batas antara tulang dengan jaringan lunak yang halus. Sedangkan pada kernel H40s Medium menghasilkan citra dengan batas antara tulang dan jaringan lunak yang cukup tegas dan kernel H70s Sharp menghasilkan batas yang tegas antara tulang dengan jaringan lunak sekitarnya.

Informasi anatomi citra merupakan hasil dari scanning MSCT Scan Orbita yang telah direkontruksi kedalam 6 variasi window dan kerne. Penilaian informasi anatomi citra menggunakan kuisioner check list yang dinilai oleh 2 responden penelitian yaitu Dokter Spesialis Radiologi. Dokter Spesialis Radiologi yang juga berperan dalam memberikan respondensi kuisioner penilaian merupakan dokter spesialis yang masih aktif bekerja serta berpengalaman dalam menilai dan memberikan ekspertise sebuah citra MSCT Scan, khususnya pada MSCT Scan Orbita. Adapun karakteristik responden pada penelitian ini dapat dilihat pada tabel 1 berikut ini:

Tabel 1. Karakteristik responden penelitian.

\begin{tabular}{cc}
\hline Responden Penelitian & $\begin{array}{c}\text { Pengalaman Ekspertise } \\
\text { MSCT }\end{array}$ \\
\hline Responden 1 & 15 tahun \\
Responden 2 & 12 tahun \\
\hline
\end{tabular}

Berdasarkan tabel 1 dapat dilihat bahwa kedua responden penelitian memiliki pengalaman kerja yang masing-masing >5 tahun, yang menandakan kedua responden telah memiliki kapabilitas yang baik dalam menilai citra MSCT Scan. Data dari hasil kuisioner check list responden selanjutnya dilakukan uji reliabilitas untuk mengetahui tingkat persamaan presepsi dalam menilai citra MSCT Scan menggunakan uji Cohen's Kappa.

Hasil dari penelitian ini dilakukan uji statistik dengan menggunakan SPSS 16 yaitu uji Cohen's kappa untuk mengetahui kesesuaian antar responden yaitu responden 1 dengan responden 2. Selanjutnya dilakukan uji Friedman untuk mengetahui perbedaan nilai variasi pada window sinus dengan kernel H30s Medium Smooth, H40s Medium, H70s Very Sharp dan window Base Orbita dengan kernel H30s Medium Smooth, H40s Medium, H70 Very Sharp terhadap informasi Citra.

Uji Cohen's Kappa adalah uji yang digunakan untuk mengetahui tingkat obyektifitas/reabilitas dari penilaian kedua responden terhadap variasi penggunaan kernel yang digunakan. Uji Cohen's Kappa digunakan untuk mengetahui tingkat kesepakatan dan objektifitas dari kedua responden terhadap penelitian ini. Uji Cohen's kappa diuji berdasarkan variasi yang sama. Adapun hasil dari uji statistik Cohen's kappa adalah sebagai berikut:

Tabel 2. Hasil uji Cohen’s Kappa Responden Penelitian.

\begin{tabular}{ccc}
\hline Informasi Anatomi & $\begin{array}{c}\text { Tingkat } \\
\text { Kesepakatan } \\
\text { R1*R2 }\end{array}$ & Kesimpulan \\
\hline Optic Nerve & 0.800 & Istimewa \\
Anterior Chamber & 0.615 & Memuaskan \\
Medial Rectus Muscle & 0.783 & Istimewa \\
Lens & 0.615 & Memuaskan \\
Lateral Rectus Muscle & 0.737 & Memuaskan \\
Dinding Orbita & 0.524 & Cukup \\
\hline
\end{tabular}

Berdasarkan hasil uji statistik Cohen's Kappa tersebut, kedua responden dalam menilai informasi anatomi hasil citra MSCT Scan orbita sudah mencapai kesepakatan yang cukup hingga istimewa dengan dilihat dari hasil nilai uji masing-masing informasi anatomi yaitu pada Optic Nerve dengan nilai kesepakatan 0.800 atau istimewa, Anterior Chamber dengan nilai kesepakatan 0.615 atau memuaskan, Media Rectus Muscle dengan nilai kesepakatan 0.783 atau istimewa, Lens dengan nilai kesepakatan 0.615 atau memuaskan, Lateral Rectus Muscle dengan nilai kesepakatan 0.737 atau memuaskan dan Dinding Orbita dengan nilai kesepakatan 0.524 atau cukup. Oleh sebab itu, dapat disimpulkan bahwa kedua responden penelitian kesepakatan dalam membaca informasi anatomi dan analisis selanjutnya dapat diambil salah satu responden yang paling berpengalaman dibidangnya. Pada pengujian ini diambil dari data penilaian responden dengan pengalaman kerja lebih dari 10 tahun. Kemudian setelah dilakukan uji statistik Cohen's Kappa dilakukan uji Friedman untuk mengetahui perbedaan dari variasi window dan kernel dari salah satu responden yang telah dilakukan uji Cohen's Kappa.

Data yang dihasilkan dari penilaian responden penelitian berupa data ordinal. Sehingga data yang dihasilkan berdistribusi tidak normal dan berpasangan, maka dilakukan uji statistik Friedman. Uji Friedman bertujuan untuk mengetahui ada ataau tidaknya perbedaan dari penggunaan variasi window dan kernel terhadap informasi anatomi citra MSCT Scan Orbita. Adapun hasil uji Friedman pada variasi window sinus dengan kernel H30s Medium Smooth, H40s Medium, H70s Sharp dan window Base Orbita dengan kernel H30s Medium Smooth, H40s Medium, H70s Sharp disajikan pada tabel 3 berikut ini: 
Tabel 3. Hasil rata-rata penilaian responden penelitian.

\begin{tabular}{lccccccc}
\hline Variasi & ON & AC & MRM & L & MLM & DO & Total \\
\hline S H30s & 22 & 22 & 18 & 17.5 & 15 & 17 & 111.5 \\
S H40s & 23 & 21.5 & 19.5 & 20 & 18.5 & 16 & 118.5 \\
S H70s & 21.5 & 20.5 & 19.5 & 25 & 20 & 21 & 127.5 \\
BO H30s & 22.5 & 21.5 & 21 & 23.5 & 26 & 23 & 137.5 \\
BO H40s & 23 & 27 & 26.5 & 24 & 23.5 & 24 & 148 \\
BO H70s & 29 & 27.5 & 26.5 & 23.5 & 25.5 & 30 & 162 \\
\hline
\end{tabular}

Berdasarkan data hasil rekap penilaian oleh responden penelitian, dapat dilihat bahwa variasi window Base Orbita dengan kernel H70s Very Sharp memiliki jumlah skor tertinggi (nilai skor 162) dibandingkan dengan variasi lainnya. Keunggulan nilai window dan kernel ini terdapat pada seluruh area anatomi yang dinilai, yaitu Optic Nerve skor terendah pada variasi Sinus H70s (nilai skor 21.5) dan tertinggi pada variasi Base Orbita H70s (nilai skor 29) Anterior Chamber skor terendah pada variasi Sinus H70s (nilai skor 20.5) (dan tertinggi pada variasi Base Orbita H70s (nilai skor 27.5) Medial Rectus Muscle skor terendah pada variasi Sinus H30s (nilai skor 18) dan tertinggi pada variasi Base Orbita H70s (nilai skor 27.5) Lens skor terendah pada variasi Sinus H30s (nilai skor 18) dan tertinggi pada variasi Base Orbita H70s (nilai skor 26.5) Lateral Rectus Muscle skor terendah pada variasi Sinus H30s (nilai skor 15) dan tertinggi pada variasi Base Orbita H30s (nilai skor 26) dan Dinding Orbita skor terendah pada variasi Sinus H40s (nilai skor 16) dan tertinggi pada variasi Base Orbita H70s (nilai skor 30)

Untuk mengetahui lebih lanjut, maka dilakukan analisa statistik. Analisa ini membandingkan enam variasi window dan kernel pada pemeriksaan MSCT Scan Orbita dan dilakukan dengan uji friedman test didapatkan hasil pada table 4:

Tabel 4. Hasil analisis uji Friedman informasi anatomi citra.

\begin{tabular}{cccc}
\hline $\begin{array}{c}\text { Area } \\
\text { Anatomi }\end{array}$ & Window dan Kernel & $\begin{array}{c}\text { p } \\
\text { Value }\end{array}$ & Ket. \\
\hline $\begin{array}{c}\text { Optic } \\
\text { Nerve }\end{array}$ & $\begin{array}{c}\text { Sinus H30s, H40s, H70s, } \\
\text { Base Orbita H30s, H40s, H70s }\end{array}$ & 0.001 & $\begin{array}{c}\text { Ada } \\
\text { beda }\end{array}$ \\
$\begin{array}{c}\text { Anterior } \\
\text { Chamber }\end{array}$ & $\begin{array}{c}\text { Sinus H30s, H40s, H70s, } \\
\text { Base Orbita H30s, H40s, H70s }\end{array}$ & 0.001 & $\begin{array}{c}\text { Ada } \\
\text { beda }\end{array}$ \\
$\begin{array}{c}\text { Medial } \\
\text { Rectus } \\
\text { Muscle }\end{array}$ & $\begin{array}{c}\text { Sinus H30s, H40s, H70s, } \\
\text { Base Orbita H30s, H40s, H70s }\end{array}$ & 0.001 & $\begin{array}{c}\text { Ada } \\
\text { beda }\end{array}$ \\
$\begin{array}{c}\text { Lens } \\
\text { Sinus H30s, H40s, H70s, }\end{array}$ & 0.001 & $\begin{array}{c}\text { Ada } \\
\text { beda }\end{array}$ \\
$\begin{array}{c}\text { Lateral } \\
\text { Rectus } \\
\text { Muscle } \\
\text { Dinding } \\
\text { Orbita }\end{array}$ & $\begin{array}{c}\text { Sinus H30s, H40s, H70s, } \\
\text { Base Orbita H30s, H40s, H70s }\end{array}$ & 0.001 & $\begin{array}{c}\text { Ada } \\
\text { beda }\end{array}$ \\
\hline
\end{tabular}

Berdasarkan hasil uji Friedman pada tabel 4.8 diatas, didapatkan nilai $p$ Value pada area anatomi Optic Nerve sebesar 0.001, Anterior Chamber 0.001, Medial Rectus Muscle 0.001, Lens 0.001, Lateral Rectus Muscle 0.001 dan Dinding Orbita 0.001, yang mana masing-masing area anatomi yang dinilai memiliki nilai signifikansi $(\mathrm{p}<0.05)$, yang menyatakan bahwa adanya perbedaan signifikan antara penggunaan variasi window sinus dengan kernel H30s Medium Smooth, H40s Medium, H70s Sharp dan window Base Orbita dengan kernel H30s Medium Smooth, H40s Medium, H70s Sharp terhadap informasi anatomi citra MSCT Scan Orbita potongan axial. Hasil uji statistik non parametrik friedman test di atas menunjukkan nilai signifikasi pada masing-masing area anatomi yang dinilai $(\mathrm{p}<0.05)$, artinya $\mathrm{H} 0$ ditolak dan $\mathrm{Ha}$ diterima, sehingga menunjukkan adanya perbedaan yang signifikan pada informasi citra anatomi dengan penggunaan variasi window dan kernel.

Pada variasi kernel dapat dilihat kernel H30s menghasilkan citra dengan batas tulang dan soft tissue yang halus, sedangkan kernel H70s menghasilkan citra dengan batas tulang dan jaringaan lunak yang lebih tajam. Hal ini sesuai dengan pernyataan bahwa dengan penggunaan kernel yang tepat, gambaran seperti tulang, soft tissue, dan jaringan-jaringan lain dapat dibedakan dengan jelas pada layar monitor (Seeram ,2016). ${ }^{[5]}$

Untuk mendapatkan gambar yang lebih halus digunakan kernel H30s atau H10s, untuk hasil yang lebih tajam dengan kernel H50s. Semakin tinggi nilai kernel (H70s atau H90s) semakin tinggi penggunaan rekontruksi algoritma maka citra semakin tajam. Pemilihan rekonstruksi kernel harus didasarkan pada aplikasi klinis tertentu (Leng, 2016) ${ }^{[9]}$ Misalnya, kernel smooth biasanya digunakan dalam penilaian organ soft tissue untuk mengurangi noise dan meningkatkan pendeteksian kontras rendah. Hal ini sesuai dengan organ soft tissue Orbita yaitu optic nerve Optic Nerve, Anterior Chamber, Medial Rectus Muscle, Lens, Lateral Rectus Muscle sehingga penilaian hasil yang didapatkan tidak berpengaruh besar, karena dengan kernel smooth organ yang akan dilihat sudah dapat ditampilkan

Di sisi lain, kernel sharp biasanya digunakan dalam uji untuk menilai struktur tulang karena kebutuhan klinis resolusi spasial yang lebih baik. dosis radiasi yang lebih rendah dapat digunakan dalam uji ini karena kontras tinggi yang melekat pada struktur. Bisa dilihat dari organ dinding orbita nilai mean rank antara pemakaian filter smooth, medium jauh lebih rendah berbeda dengan pemakaian filter Sharp yang nilai mean ranknya sangat tinggi, hal ini disebabkan organ ini adalah merupakan struktur tulang.

Berdasarkan hasil analisis secara bivariat menggunakan metode uji Friedman untuk melihat ada tidaknya perbedaan antara variabel serta mengetahui variable mana yang lebih baik. Uji perbedaan yang dilakukan bertujuan untuk melihat perbedaan informasi anatomi citra MSCT Scan Orbita potongan axial dengan variasi window dan kernel. Berdasarkan hasil pengujian 
yang ditampilkan pada tabel 4.9. didapatkan bahwa area anatomi Optic Nerve, Anterior Chamber, Medial Rectus Muscle, Lens, Lateral Rectus Muscle dan Dinding Orbita masing-masing memiliki nilai signifikansi $(\mathrm{p}<0.05)$, yang menyatakan bahwa adanya perbedaan signifikan antara penggunaan variasi window sinus dengan kernel H30s, H40s, H70s dan window base orbita dengan kernel H30s, H40s, H70s terhadap informasi anatomi citra MSCT Scan Orbita.

Berdasarkan hasil uji statistik non parametrik friedman test di atas menunjukkan nilai signifikasi pada masing-masing area anatomi yang dinilai $(\mathrm{p}<0.05)$, artinya $\mathrm{HO}$ ditolak dan Ha diterima.

RS PKU Muhammadiyah Kabupaten Karanganyar yang menjadi tempat pengambilan data ini menangani pemeriksaan MSCT Scan Orbita, terdapat rata-rata 5-10 pasien/bulan dengan mayoritas kasus yaitu trauma. Windowing dan kernel yang digunakan selama ini ialah window base orbita dengan kernel H31s.

Berdasarkan literature yang peneliti dapatkan, pemilihan rekonstruksi kernel harus didasarkan pada aplikasi klinis tertentu. Pada kasus trauma, perlu diperhatikan struktur tulang serta jaringan lunak disekitar objek, sehingga diperlukan windowing yang dapat menampilkan struktur ssoft tissue yang baik dengan kombinasi kernel yang tajam yaitu H70s Very Sharp untuk memberikan batas tegas antara tulang dan jairngan lunak.

Untuk mengetahui variasi window dan kernel mana yang lebih baik dalam mevisualisasikan informasi anatomi citra pada pemeriksaan MSCT Scan Orbita potongan axial dengan penggunaan variasi window dan kernel, dapat dilihat pada tabel 5 hasil mean rank pada uji Friedman.

Tabel 5. Hasil mean rank uji Friedman.

\begin{tabular}{cccccccc}
\hline $\begin{array}{c}\text { Window } \\
\text { dan }\end{array}$ & \multicolumn{4}{c}{ Rank Area Anatomi } & & $\begin{array}{c}\text { Mean } \\
\text { Total }\end{array}$ \\
Kernel & ON & AC & MRM & L & LRM & DO & \\
\hline S-H30s & 1.70 & 1.00 & 1.35 & 1.45 & 2.05 & 1.85 & 1.56 \\
S-H40s & 2.35 & 2.55 & 2.50 & 2.85 & 2.30 & 2.35 & 2.48 \\
S-H70s & 3.10 & 3.10 & 3.40 & 3.15 & 3.20 & 3.30 & 3.20 \\
BO-H30s & 4.10 & 3.60 & 4.00 & 4.00 & 3.95 & 3.80 & 3.90 \\
BO-H40s & 4.65 & 4.60 & 4.75 & 5.05 & 4.15 & 4.10 & 4.45 \\
BO-H70s & 5.10 & 5.20 & 5.00 & 4.50 & 5.35 & 5.60 & 5.21 \\
\hline
\end{tabular}

Berdasarkan hasil mean rank uji Friedman pada tabel 5 diatas didapatkan organ Optic Nerve untuk nilai yang tertinggi yaitu pada variasi rekonstruksi Base orbita H.70s Very Sharp, dengan nilai 5.10 kemudian nilai terendah pada variasi rekonstruksi Sinus H.30s Smooth, dengan nilai mean rank 1.70.

Untuk organ Anterior Chamber untuk nilai yang tertinggi yaitu pada variasi rekonstruksi Base orbita H.70s Sharp, dengan nilai 5.20 kemudian nilai terendah pada variasi rekonstruksi Sinus H.30s Smooth, dengan nilai mean rank 1.0.

Untuk organ Medial Rectus Muscle untuk nilai yang tertinggi yaitu pada variasi rekonstruksi Base orbita H.70s Sharp, dengan nilai 5.00 kemudian nilai terendah pada variasi rekonstruksi Sinus H.30s Smooth, dengan nilai mean rank 1.35.
Untuk organ Lens untuk nilai yang tertinggi yaitu pada variasi rekonstruksi Base orbita H.40s Medium, dengan nilai 5.05 kemudian nilai terendah pada variasi rekonstruksi Sinus H.30s Medium Smooth, dengan nilai mean rank 1.45

Kemudian organ lateral Rectus Muscle untuk nilai yang tertinggi yaitu pada variasi rekonstruksi Base orbita H.70s Very Sharp, dengan nilai 5.35 kemudian nilai terendah pada variasi rekonstruksi Sinus H.30s Smooth, dengan nilai mean rank 2.05

Untuk dinding orbita untuk nilai yang tertinggi yaitu pada variasi rekonstruksi Base orbita H.70s Very Sharp, dengan nilai 5.60 kemudian nilai terendah pada variasi rekonstruksi Sinus H.30s Smooth, dengan nilai mean rank 1.56

Berdasarkan hasil mean rank uji Friedman pada tabel 5 diatas, didapatkan bahwa area anatomi Optic Nerve (ON), Anterior Chamber (AC), Medial Rectus Muscle (MRM), Lens (L), Lateral Rectus Muscle (LRM) dan Dinding Orbita (DO) yang dinilai menunjukkan hasil mean total pada window sinus H30s Medium Smooth sebesar 1.56, window sinus H40s Medium sebesar 2.48, window sinus H70s Sharp sebesar 3.20, window base orbita H30s Medium Smooth sebesar 3.90, window base orbita H40s Medium sebesar 4.45 dan window base orbita H70s Very Sharp sebesar 5.05 Pada hasil tersebut dapat dilihat bahwa penggunaan variasi window base orbita dengan kernel H70s Very Sharp memiliki nilai mean total yang lebih tinggi dibandingkan variasi window dan kernel lainnya dengan nilai 5.05, sehingga variasi tersebut dapat memvisualisaikan area anatomi MSCT Scan Orbita potongan axial lebih baik.

Kernel sharp biasanya digunakan dalam uji untuk menilai struktur tulang karena kebutuhan klinis resolusi spasial yang lebih baik (Leng, 2016) Hal ini sesuai dengan hasil penilaian yang dilakukan oleh responden saat menilai variasi kernel yang paling baik dalam -mendukung diagnosa MSCT Scan orbita pada kasus trauma orbita. Trauma tumpul pada mata dan daerah orbita dapat menyebabkan kerusakan pada dinding tulang orbita yang relatif tipis. Trauma secara langsung (direct) maupun tidak langsung (indirect) dapat menyebabkan fraktur pada tulang orbital. ${ }^{[9]}$

MSCT Scan Orbita merupakan pilihan utama untuk mendiagnosis fraktur, disarankan untuk melakukan pemeriksaan MSCT Scan dengan potongan coronal dan axial, dan harus diprioritaskan untuk mendapatkan gambaran lantai dasar orbita dan canalis nervus opticus. Dengan penggunaan kernel H70s Very Sharp pada kasus trauma orbita, gambaran struktur tulang dapat terlihat dengan sangat jelas dan detail yang tinggi, sehingga radiolog dapat mendiagnosa sampai dengan gambaran lantai dasar orbita dan canalis nervus opticus dengan baik.

\section{Simpulan}

Pada variasi window sinus $\mathrm{H} 30$ s medium smooth dan $\mathrm{H} 40$ s medium dan window sinus $\mathrm{H} 70$ s very sharp 
menampilkan dinding orbita. dan yang paling jelas pada window sinus $\mathrm{H} 70 \mathrm{~s}$ very sharp. Pada window base orbita H30s medium smooth dan H40s medium.menampilkan kejelasan pada anterior chamber,lens dan medial rectus muscle. Pada window base orbita H70s very sharp menampilkan kejelasan pada optic nerve, anterior chamber, lateral rectus muscle dan dinding orbita. Dalam uji statistik terdapat perbedaan informasi anatomi citra pada masing masing organdengan nilai $p$ value 0.001 yang artinya terdapat perbedaan antara tiap variasi rekonstrusi.

Informasi anatomi citra yang lebih baik antara variasi window sinus dengan kernel H30s Medium Smooth, H40s Medium, H70s Very Sharp dan window base orbita dengan kernel H30s Medium Smooth, H40s Medium, H70s Very Sharp pada pemeriksaan MSCT Scan Orbita potongan Axial pada kasus Trauma dihasilkan bahwa pengunaan window base orbita dengan kernel H70s Very Sharp merupakan variasi terbaik dalam menampilkan informasi anatomi citra

\section{Daftar Pustaka}

Bushberg, J. (2012). The Essential Physics of Medical Imaging. Third Edition. Lippincott Williams \& Wilkins

Dahlan, M.S. (2016). Besar Sampel Dalam Penelitian Kedokteran Dan. Kesehatan. Jakarta: Epidemiologi Indonesia.

Kementrian Kesehatan Republik Indonesia (Kemenkes RI). (2014). Riset Kesehatan Dasar 2013 (RISKESDAS).

[Internet] http://kesga.kemkes.go.id/images/pedoman/Data \%20Riskesdas\%202013.pdf. Diakses pada 6 Januari 2019

Sherwood, L. (2011). Fisiologi Manusia dari Sel ke Sistem. Edisi: 6. Terjemahan: dr. Brahm U. Pendit. Editor: dr. Nella Yesdelita. Jakarta: Penerbit Buku Kedokteran EGC.

Seeram, E. (2016). Computed Tomography: Physical Principles, Clinical Aplications, and Quality Control. Fourth edition. WB Saunders Company, Philadelphia

Siemens. (2013). Instruction for Use SOMATOM syngo CT. GermanWilianto, W. (2012). Trauma Tumpul pada Mata yang Meyebabkan Kebutaan. Jurnal Kedokteran Forensik Indonesia 14(3) Departemen Ilmu Kedokteran Forensik dan Medikolegal FK UNAIR

.Wahab, M., Kader A., \& Ibrahiem, M. (2014). The Role of Multi Detector Computerized Tomography in Evaluation of Maxillofacial Fractures. The Egyptian Journal of Radiology and Nuclear Medicine 45. [Internet] https://www.sciencedirect.com/science/article/pii /S0378603X13001435. (Diakses pada 22 Februari 2019). 